\title{
制度改革WG報告
}

Report on the Working Group of Improvements and Renewal on JSEE Operating System

\author{
中 山良一※1 \\ Ryoichi NAKAYAMA
}

1.はじめに

「制度改革WG」は，事業企画委員会（委員長：石 川憲一 金沢工業大学学長) の $4 \mathrm{WG}$ の一として 2 年 間にわたり，前WGである「サービス向上検討WG」 （山村弘 WG主査）の検討項目・内容を引き継ぎ，そ の実施方法などの具体的な議論を行ってきた．昨年の 公益社団法人日本工学教育協会 (以下日工教) 年次大 会（第59回）での中間発表と，そこでのご意見を含め てWGとして検討した結果を報告する.

これらの検討内容については，その一部は既に実際 に運用段階に入っているものも多く，まさに本WGは 議論した結果をすぐに実践することで，事務局を支援 する体制を構築していると言える。しかし，まだ多く の課題を有しており, これからの検討, 実践活動への 会員をはじめとする関係者のご協力を期待する.

\section{2. 制度改革とは}

日工教は，本年創立60周年を迎える組織であり，各 種の事業, 活動を企画・運営してきている。 その多く は，継続的に実施してきているが，昨今の急激な環境 変化 (大学全入時代, グローバル化の進展, 大学・高 専の教育評価の浸透など）に対して適切に対応できて いるとは言えない状況となっている．合わせて一昨年 (平成 22 年年度下半期) からの公益法人化により, 会員 向けの限定事業から一般者に対する公的な事業への大 きな転換も含めて, その課題抽出・検討・実践が求め られてきている.

この環境変化に対する状況認識は，前 WGにおいて も同一であり,「会員」限定のサービスから一般者を も含めたサービスについての検討を行ってきた ${ }^{11}$.

ポイントは 2 点であり, 1 )「会員」向けから「全て の方々」へ向けた活動が求められていること，2）従 来の「組織中心の観点」から「顧客の観点」への変貌 が求められていることである．特に後者については, 組織運営メンバー全員がこの変貌を認識・意識し, 各 種の活動への取り組みを通じて, 日工教の変化を示す ことがポイントとなっている.

2012 年 9 月 10 日受付

※1 工学院大学グローバルエンジニアリング学部機械創造学科
これらの観点を意識し, 本WGのミッションと主た る活動アイテムを次のように定義した。

一事業企画委員会での議論を踏まえて, 日工教の各 種制度を新たに構築または, 従来の各種制度も将 来を見据えて改変することをミッションとする.

一主たる活動アイテム

日工教の「存在」を知らせること.

特に, 会員自身も「知らない」ことが問題点である. まず，日工教と地区工教の関係や体制をはじめとし て, 会員制度, 教育士（工学・技術）（以下教育士）制 度, 報奨制度などの存在自身を知らない, また知って いても内容を正しく把握していない.

このために,「会員（顧客）の目線（観点）」での戦 略的な広報活動が日工教に求められる。

\section{3.これまでの検討課題}

本WGには, 日工教委員 10 名と事務局委員 2 名が検 討メンバーとして参加している. 委員構成は, 大学・ 高専の教員が 6 名, 企業関係者 4 名となっている.

検討課題は，大きく分けると以下の通りである.

(1) 会員制度の検討

(2) 教育士制度の検討

(3) 地区工教と日工教の関係検討

（4）報奨制度の検討

(5) 広報活動の検討

これら各課題の背景は, 前述の通り, 会員であって も各種制度を知らないために,「制度が有効に活用され ていないこと」.さらには会員構成として団塊世代が多 数属しているために, 彼らが「教員を引退する時期を 迎え, そのまま退会となること」. この退会を防止する 制度的な対策が必要であるなどである。

(1) 会員について

特に, 表 1 に示すように正会員数は, 平成19年度 3,528名をピークとして, 平成 23 年度は3,270名と 258 名 （6.8\%）の急激な減少となっている. また, 団体会員で も学校会員, 企業会員が平成19年度以降平成23年度ま でに, 各々 13 団体, 22 団体が退会している.

この会員減少の中でも, 学校個人会員は268名 $(8.3 \%)$ も減少しており, この対策が求められている.

(2) 教育士制度について 
表 1 最近 5 年間の会員数の推移（単位：数, 名)

\begin{tabular}{|c|c|c|c|c|c|}
\hline 年度 & 学校団体 & 企業団体 & 学校個人 & 一般個人 & 個人合計 \\
\hline H19 & 220 & 63 & 3,228 & 300 & 3,528 \\
\hline H20 & 219 & 55 & 3,207 & 303 & 3,510 \\
\hline H21 & 216 & 49 & 3,191 & 310 & 3,501 \\
\hline H22 & 209 & 44 & 3,061 & 310 & 3,371 \\
\hline H23 & 207 & 41 & 2,960 & 310 & 3,270 \\
\hline
\end{tabular}

各年度末の会員数（個人会員はWeb会員を含む）

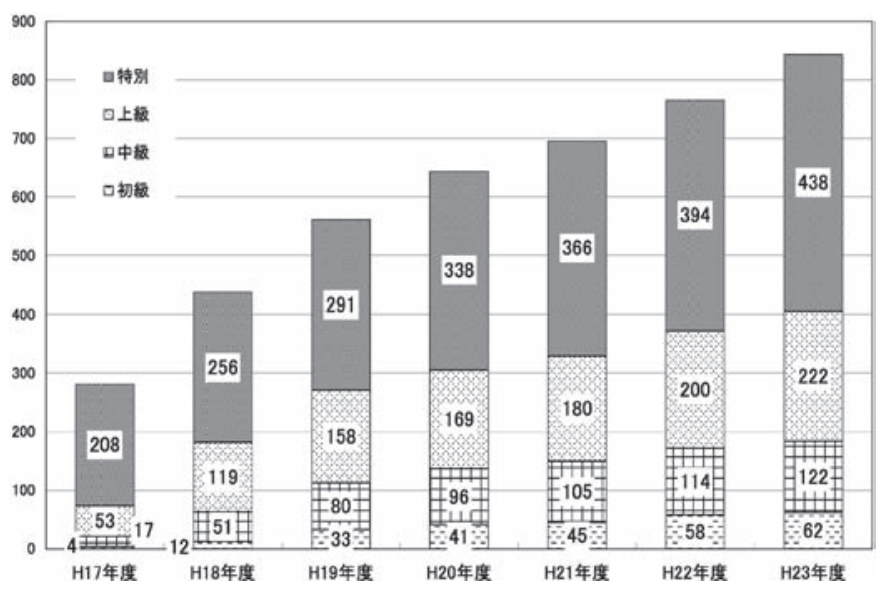

図 1 教育士（工学・技術）取得者累計

教育士制度は，日工教が平成 17 年度に日本初の制度 として導入した理工学系教員の教育力を保証する資格 であり，既に累計844名を認定している.

しかし，平成17年度から18年度にかけて $50 \%$ と急増 したが, その後平均 $10 \%$ 程度の増加に止まっており, 教 育士制度が定着しているとは言い難い状況である。平 成23年度までの教育士累計総数 844 名は, 日工教個人会 員の約 $25 \%$ である。これらの問題解決について教育士 委員会を中心としての解決策検討が求められている.

(3) 地区工教と日工教の関係について

昭和 27 年に発足した地区工教と日工教の関係は，当 初各地区での工学教育の充実に重点をおき活動は推進 され, 日工教は各地区の主要メンバーによる連絡組織 であった。

その後, 個人会員としての各種活動が活発となると 共に, 全国組織としての活動が中心となる様に至り, 一昨年度の日工教の公益法人化を機会に, 全国的な組 織と地区組織をどの様に䌂めるべきかの議論を少しず つ始めている。現在の課題は, 地区工教のみに所属し ている個人会員の扱い, 各地区工教の会費の相違など であり，なるべく早急に議論すべき問題であるとの認 識を持っている.

（4）報奨制度について

日工教の表彰制度は，下記の 2 種類がある。

一日本工学教育協会賞 (平成 3 年発足)

日工教40周年を記念して, 協会の会員を対象とす る表彰として, 各地区工教, 学校会員, 企業団体 会員, 賛助会員などからの推薦に基づく, 日工教
の会長による表彰.

一工学教育賞 (平成 8 年発足)

日工教45周年を記念して, 高等教育機関からの推 薦に基づいての表彰で, 最優秀 1 件は文部科学大

臣賞を授与する表彰.

上記 2 表彰は，共に重複する部分も多くあり，60周 年を記念して, 両賞の主旨を生かしながら発展的に統 合する方向で検討した。

また，日工教の活動に顕著な貢献がある会員の方々 に対しての表彰(奨励または感謝表彰的な要素を含む) 制度を検討した。

（5）広報活動について

日工教では，広報活動委員会を組織して，各種イベ ントの周知方法の検討などしてきているが, 昨今の激 動する社会変化への対応が遅れているとの意見も多数 ある。これらのご指摘に対して, 協会の「顔」である ホームページを他学協会に近いレベルまで改良するこ とを検討した。前述の個人会員獲得に向けたサービス にも繋げること, また多数の方々に対して日工教の活 動内容を「見える化」できる方式を検討した.

\section{4. 本WGでの検討内容および結果}

前記の 5 項目について 2 年間で議論した内容および 一部項目については, 既に本年度より実施している内 容も含めて以下に纏める.

(1) 会員制度について

一昨年度までの会員制度検討では, 現行の個人会員 の分類を増やすことで会員獲得（減少対策）を困る案 を検討した。

具体的には 1）高校生までのジュニア会員，2）大 学生または大学院生の学生会員（18歳以上30歳までの 学生）とリタイアした方々については，3）終身会員 (一括の定額払いのみ), 4 ） シニア会員（年間のWeb 個人会員より若干割引）を検討した。

今回は4）シニア会員の制度を具体化することにし た。 その理由は, 日本では定年退職者が一時的に増加 することへの会員対策が必要との観点である．既に， 昭和 20 年代前半のベビーブーム時代に生まれた方々の リタイアは，企業においては2007年問題（平成17年） などと称されて, 主として年金問題がクローズアップ されていた。しかし, 各社では再雇用制度の導入によ る優秀な技術者や技能者を低賃金での留保や，他社か らの技術者の獲得で人材流出問題は, 一段落している.

一方, 教育機関では, 従来の定年を早期化するなど の施策により, 教員の退職が平成20年以降徐々に増え, この結果日工教退会者が増加してきている. そこで昨 年 5 月の本 WGで, シニア会員を追加することとし, 理 事会と社員総会を経て, 本年より適用を開始した。例 年 3 月から 4 月の会員移動にあたって, 退職を理由と する退会者が多数出ていたが, 本シニア会員の制度に 


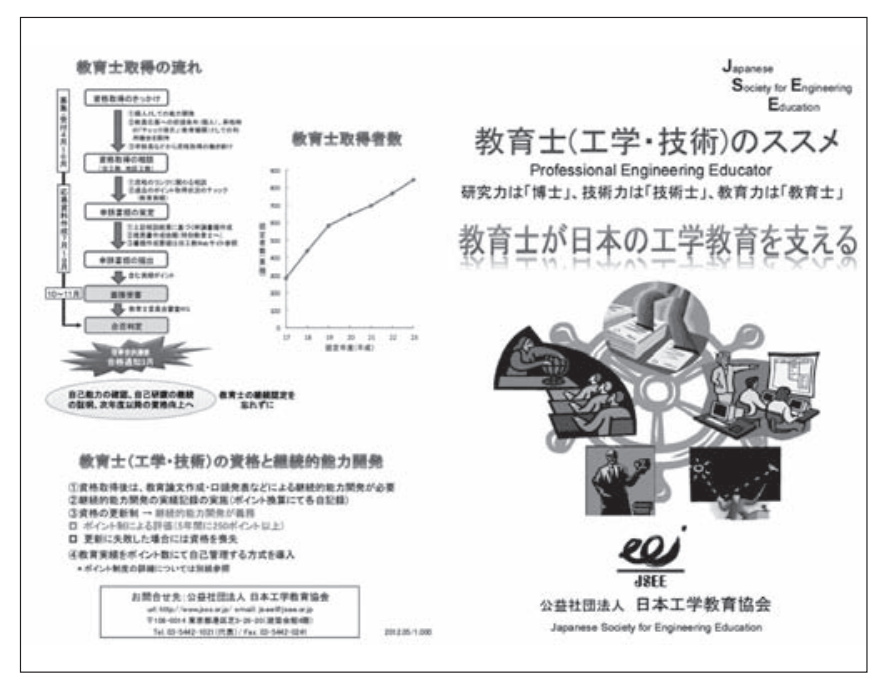

〈表〉

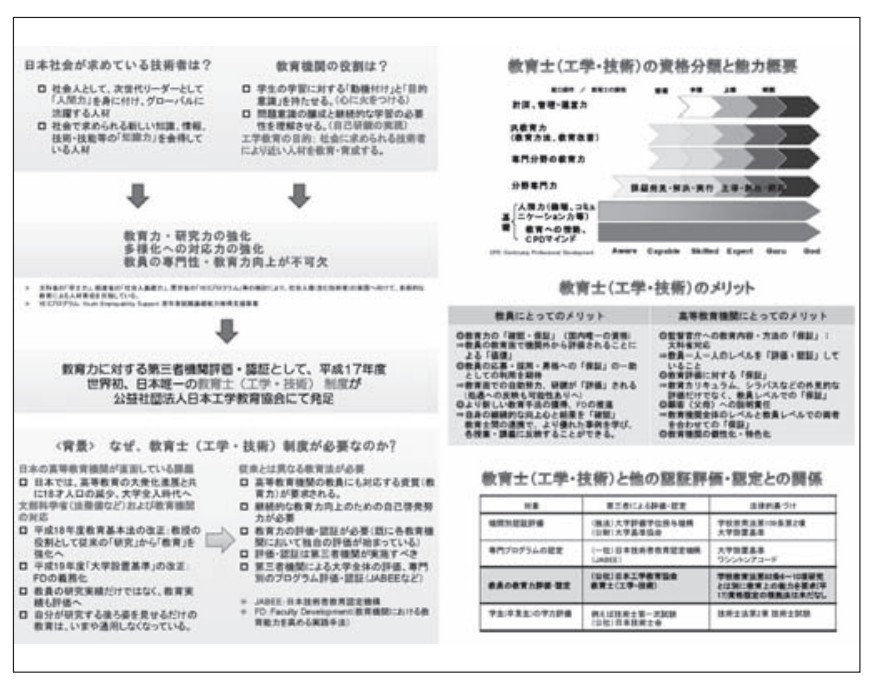

〈裏〉

図 2 教育士のパンフレット（2012年度版）

より, 本年以降も継続する方々が 7 名いらした。この 点では若干の会員減少の歯止めとすることができた.

〈シニア会員制度〉

日工教年会費（除く地区工教会費）………2, 2,000円

「工学教育」誌………………….... Web で閲覧

総会議決権…………………………………. あり

会員割引制度…………………………………適用

会員区分条件……年齢 67 歳以上, 会員歴 5 年以上

なお，学生会員については，一般専門学会と当協会 は会員構成に差異（学生参加者が少ない点）があり, 当面は年次大会の参加費軽減措置（一般個人会員の半

額）とすることのみで対応することとした.

(2) 教育士制度について

新しい教育士の獲得に向けて, 昨年度よりパンフレ ットを検討してきた．教育士委員会メンバーとも協力 して検討し，資格の必要性，メリットなどを分かり易 く解説し, 手続きについてもフローで示すことで, 取 得の準備などにも役立つものとした.

第60回日工教年次大会（関東工教共催：芝浦工業大 学 豊洲キャンパス)にて, 本パンフレットを参加者 に配布するなどして, 教育士制度の広報活動に活用し た.

なお，教育士の継続にあたって，過去 5 年間のポイ ントの申請が必要となっているが, 教育士委員会と協 力して, ポイントの説明などより分かり易い表現とす るなど, 制度としての利便性の向上を図った。

ポイントの改訂内容について,「工学教育」誌㧍よび ホームページで周知を徹底した。

(3) 地区工教と日工教の関係について

公益法人化の実施に引き続き, 一昨年度末に前任の 山村 WG 主查と剣持専務が地区工教を訪問して, 本件 検討についての打診を行った.

地区工教の目線で, 地区のみの個人会員の取り扱い, ま た地区別会費の相違などの課題があることを確認した。

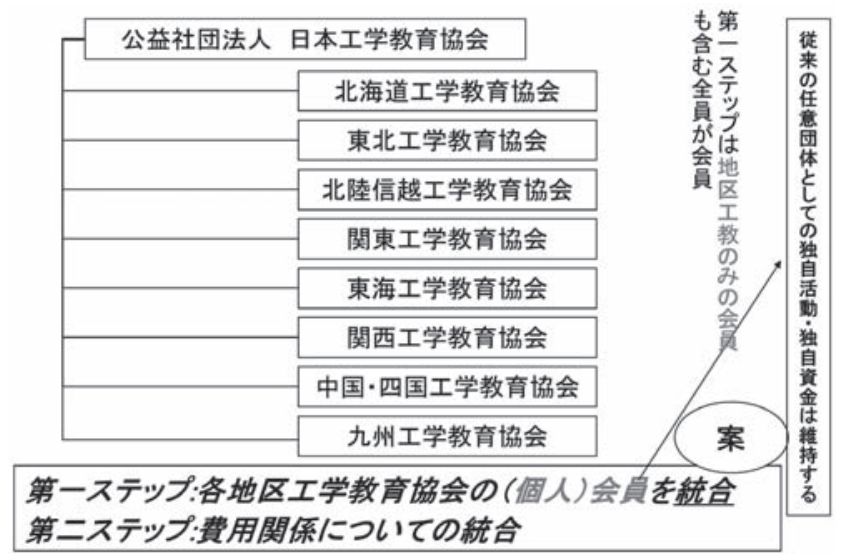

図 3 地区工教と日工教の今後について（案）

一方, 最近の個人会員にとっては, 地区工教は日工 教の支部（同一法人）であると思っている方々も多く なっているようで, 永年の課題である両者の関係を少 し整理する時期に来つつあると考え, 本WGでは図 3 に示すように，第一ステップでは，会員を統合し日工 教は各地区工教の連合体とする試案を策定しました。

本試案では, 次のステップで会費（個人, 団体会員） の統合を図る案を検討し, 地区工教のみの会員に対し ても日工教会員と同一（雑誌の配布はなしでWebの み）とすることで, 各個人会員が日工教会員のメリッ 卜を感じて，その後に正式会員となってくれるのでは との期待を想定して検討した.

なお当面, 地区工教は任意団体としての独自活動, 独自資金は維持するものとし, 各地区工教の意向に応 じて，体制を集約すること検討したい，本WGでは， 公益社団法人に対するインパクトは少ない方向で調整 できると考えている.

\section{（4）報奨制度について}

前述の 2 表彰を統合化することで，本年度の募集よ り実視することとした。なお，日工教の活動に顕著な 貢献がある会員の方々に対しての表彰（奨励または感 


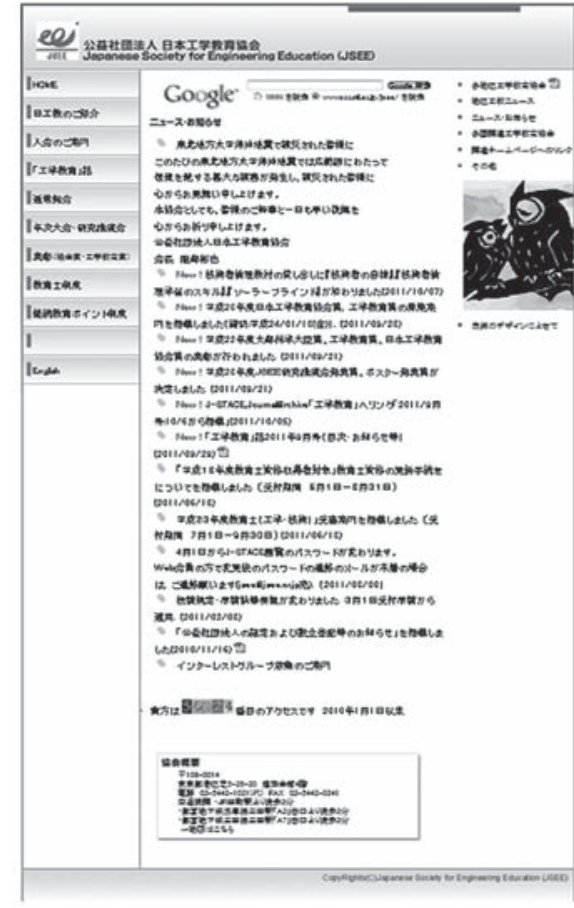

旧ホームページ：2012年 3 月末まで

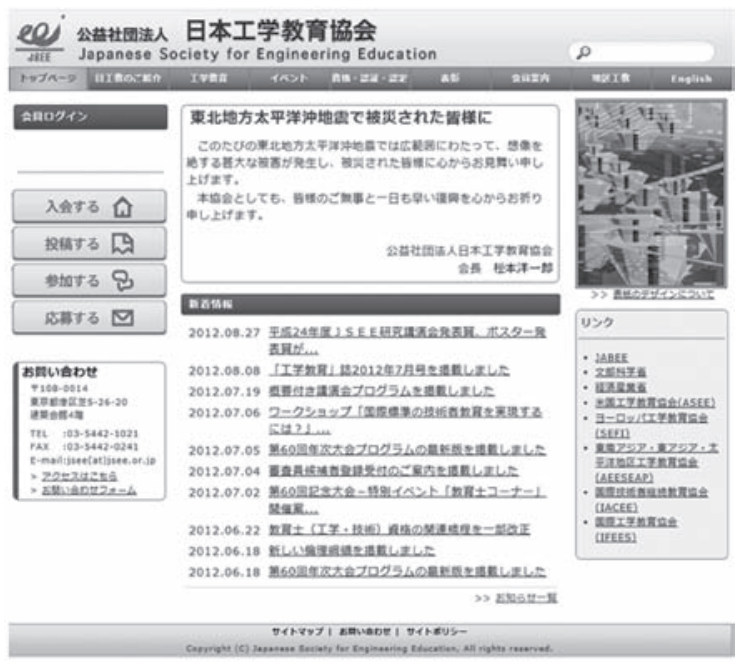

新ホームページ：2012年 4 月より

図 4 日工教ホームページ

(アドレス : https://www.jsee.or.jp/)

謝表彰的な要素を含む）制度については, JSEEアウォ ードとして，運用細則を検討中である。本表彰は，各 委員会委員長や主査の提案で, 簡便に表彰できること とし，会員への謝意を表するものとし，表彰も社員総 会で行う方向としている.

（5）広報活動について

当面の課題であるホームページについては，下記の 方針で改訂することとした.

一個人ページの導入

一お知らせページの充実

- 将来の課題として, 理事会, 委員会などの出欠管 理

－過去のデータベースの会員向け公開

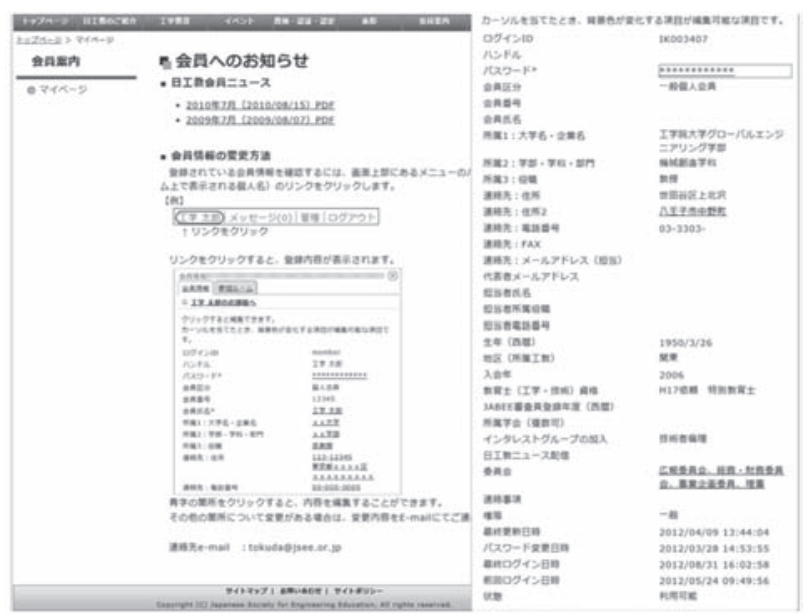

図 5 会員ページのデータ（サンプル）

昨年12月の本 WGの検討結果に基づいて，本年 1 月 より事務局が設計・製作を発注し，なるべく既存のソ フトを活用して，早期に開設できる様にして，短納期 で 3 月下旬に完成した（図 4,5参照)。

従来のホームページに比較して，レイアウトを縦方 向から横方向として, タブ切換の導入により一覧性を 向上して，利用しやすくした，会員ログインから個人 情報を会員本人が修正できる。 また更新デー夕を会員 データベースにも反映できるなど，色々な点で改善を 行った.

本ホームページは, 既成のソフトを用いており, 標 準的な機能についても未だ利用していないもあり, 今 後更なる利便性の向上が期待されている. 会員の皆様 方からの運営法や利用法などに対する提案があれば事 務局にご一報頂きたい.

\section{5.おわりに}

事業企画委員会のもと, 本WGでは先の「サービス 向上WG」の議論を受けて, 比較的身近な課題を議論・ 検討し, 解決することができた. しかし, 地区工教と 日工教の関係, 教育士制度の改良, 教育士の拡大, 広 報活動の充実など，多くの課題が残されている.

今回の提案について, 実効のあるものとすべく更な る皆様方のご協力宜しくお願い申し上げる.

\section{【本WGメンバー】}

主 查：中山良一

委 員: 雑賀 高, 清尾克彦, 中崎良成, 岡本延 美, 青木宏之, 椿原 治, 酒井茂男（代理 大曽根正紀), 田宮直彦, 川高美由紀

事務局：剣持庸一, 山口ふ2子

\section{参 考 文 献}

1) 山村 弘: サービス向上策検討WG報告, 工学教育, $58-6$, pp. $79-81,2010$ 